\title{
Kombinasi Metode Kontrol dan Perkuatan untuk Penanganan Longsor (Studi Kasus: Longsor Waikerap, Tanggamus, Lampung)
}

\author{
Aminudin Syah*'1 ${ }^{1}$ Ilham Dani ${ }^{2}$, Sandri Erfani ${ }^{2}$ \\ ${ }^{1}$ Jurusan Teknik Sipil, Fakultas Teknik, Universitas Lampung, Indonesia \\ ${ }^{2}$ Jurusan Teknik Geofisika, Fakultas Teknik, Universitas Lampung, Indonesia \\ E-mail : aminudin.syah@eng.unila.ac.id
}

Received 09 October 2020; Reviewed 16 October 2020; Accepted 07 December 2020 Journal Homepage: http://jurnal.borneo.ac.id/index.php/borneoengineering

\begin{abstract}
Landslides often cause heavy casualties and material losses in Tanggamus Regency. These incidents continues to be repeated so that it still requires for a landslides risk reduction. Landslides risk mitigation begins with a field survey and soil investigation, followed by analyzing the investigation results and planning the potential mass movements. The results from the geological survey shows that the study area has a litology of constituents in the form of andesite and landslide material in the form of volcanic breksi with a high level of weathering so as to form a thick layer of soil. The basic landslide handling design plan in Pekon Waykerap is to perform the geometry arrangement of the slopes so it provides a strengthened structure with gabion slopes. The slope design results gives the slope height limited to 5 meter, a 1H:1V slope gradient, and 2.5 meter bench. The slope surface is suggested to be covered with a patch of grass and equipped with surface drainage. The slope stability analysis results for Pekon Waykerap landslides using the limit equilibrium method shows that using the combination of control and retrofitting method and increases the static safety factor from 1.092 to 1.298 and the dynamic safety factor from 0.846 to 1.031, which means the ground mass movement risk decreases.
\end{abstract}

Keywords: Slope Stability, landslide, mitigation, Tanggamus, control work

\begin{abstract}
Abstrak
Bencana longsor seringkali menimbulkan korban jiwa dan kerugian material yang besar di Kabupaten Tanggamus. Kejadian ini terus berulang sehingga masih membutuhkan upaya pengurangan risiko bencana longsor. Kegiatan ini diawali dengan survei lapangan dan penyelidikan tanah, kemudian dilakukan analisis data hasil investigasi serta perencanaan penanganan potensi gerakan massa dengan kombinasi metode kontrol dan perkuatan. Hasil survei geologi menunjukkan bahwa pada lokasi pengamatan longsor yang diamati memiliki litologi penyusun berupa andesit dan material longsoran berupa breksi vulkanik dengan tingkat pelapukan yang tinggi sehingga membentuk lapisan tanah yang tebal. Perencanaan basic design untuk penanganan longsor di Pekon Waykerap adalah melakukan penataan geometri lereng serta memberi struktur perkuatan pada kaki lereng berupa bronjong. Penataan lereng dilakukan dengan membatasi ketinggian lereng sebesar 5 meter, mengatur kemiringan lereng menjadi $1 H: 1 \mathrm{~V}$, serta memberikan bench/trap sebesar 2,5 meter. Pada permukaan lereng harus ditutupi dengan gebalan rumput dan diberikan drainase permukaan. Hasil analisis stabilitas lereng dengan metode keseimbangan batas (limit equilibrium) pada contoh penanganan longsor di Pekon Waykerap menunjukkan bahwa dengan penanganan kombinasi metode kontrol dan perkuatan meningkatkan nilai faktor aman dari 1,092 (statis) dan 0,846 (dinamis) menjadi 1,298 (statis) dan 1,031 (dinamis) yang berarti lereng memiliki risiko kecil terhadap gerakan massa tanah.
\end{abstract}

Kata kunci: Stabilitas lereng, longsor, mitigasi, Tanggamus, metode kontrol 


\section{Pendahuluan}

Berdasarkan data Indeks Risiko Bencana Indonesia (IRBI), Kabupaten Tanggamus tergolong sebagai kabupaten yang memiliki kelas risiko tinggi (skor 201) dengan peringkat 58 se-Indonesia, tanah longsor memiliki kelas risiko tinggi (BNPB, 2014). Badan Penanggulangan Bencana Daerah (BPBD) Kabupaten Tanggamus menyebutkan hujan dengan intensitas tinggi yang terjadi pada tanggal 29 -10 Oktober 2018 mengakibatkan banjir dan tanah longsor di beberapa titik di Pekon Waykerap dan Pekon Sedayu. Kejadian ini mengakibatkan akses jalan lintas provinsi terputus dan sejumlah rumah dan sekolah terendam banjir dan tertimbun longsor. Kejadian terbaru terjadi pada 9 Januari 2020. Longsor dan banjir bandang yang menerjang Pekon Waykerap dan Pekon Sedayu mengakibatkan 483 rumah rusak dan lebih dari 300 lahan pertanian terutama sawah, rusak berat. Selain itu, longsor menutup akses jalan lintas menuju Bengkulu. Berdasarkan peta kerentanan gerakan tanah di Provinsi Lampung (BNPB, 2013). Pekon Waykerap adalah daerah dengan potensi gerakan tanah menengah hingga tinggi. Besarnya kerugian akibat musibah ini menuntut penanganan yang efektif bagi berbagai pihak terkait untuk dapat mengatasinya.

Mitigasi longsor dapat dilakukan secara struktural dan non-struktural. Penelitian ini membahas upaya penanganan longsor secara struktural. Konsep penanganan longsor yang diberikan dapat dianalisis stabilitasnya menggunakan metode kesetimbangan batas. Metode kesetimbangan batas adalah salah satu metode tertua untuk menentukan permukaan slip kritis dan faktor keamanan minimum. Sebagian besar metode untuk menghitung stabilitas lereng didasarkan pada prinsip keseimbangan gaya dan momen (Haji Azizi dkk. 2015). Dalam metode ini, kegagalan diasumsikan terjadi pada permukaan kegagalan tertentu. Oleh karena itu, diperlukan tegangan geser untuk menjaga keseimbangan dengan kuat geser tanah yang dibandingkan dan dihitung faktor keamanan lereng. Proses ini dilakukan untuk beberapa permukaan yang berbeda dan permukaan dengan faktor keamanan minimum, karena permukaan yang berpotensi rusak dan faktor keamanan yang terkait diterima sebagai jawaban dari masalah tersebut. Mode permukaan kegagalan berbeda-beda tergantung pada jenis material penyusun lereng dan dapat berupa bidang, lingkaran, lengkung atau logaritmik atau kombinasi keduanya. Jika bahan penyusunnya homogen maka permukaan keruntuhan akan mendekati lingkaran (Rahimi 2013). Dengan demikian, tergantung pada asumsi yang dibuat, beberapa metode telah dikembangkan yang memberikan faktor keamanan yang berbeda, di antaranya metode ini dapat diperoleh dengan menggunakan metode Fellenius (Fellenius 1927), metode Bishop yang dimodifikasi (Bishop dan Morgensrern 1960), keseimbangan kekuatan Lowe dan Karafath (1960), metode Janbu yang dimodifikasi (Janbu 1973), metode Korps Insinyur Angkatan Darat AS (1970), metode Spencer (Spencer 1967), metode Morgenstern-Price (Morgenstern dan Harga 1965) dan metode Sarma ( Sarma 1973). Metode yang dikembangkan oleh Morgenstern dan Price (1965) dapat menguji kestabilan lereng pada semua permukaan keruntuhan (dalam bentuk apapun) dan menghitung faktor keamanan. Dalam metode ini, tidak hanya gaya tangensial dan normal, tetapi juga keseimbangan momen untuk setiap irisan disediakan (Morgenstern 1963)

Steward dkk. (2011) mempelajari stabilitas lereng yang berbeda dalam hal geometri dan material menggunakan perangkat lunak SLOPE/W. Hasil penelitian menunjukkan bahwa permukaan kegagalan sebagian besar berada pada jenis lingkaran jari kaki, namun pada beberapa kasus dapat juga berada pada jenis lingkaran titik tengah. Penelitian yang dilakukan oleh Salmasi F dkk. (2019) menunjukkan bahwa penurunan muka air tanah dan menghilangkan tekanan hidrostatis pada lereng akan mengakibatkan penurunan faktor keamanan. Perbandingan bidang longsor berbentuk lingkaran dan planar menunjukkan bahwa bidang longsor berbentuk planar memberikan hasil yang baik hanya untuk lereng yang mendekati vertikal. Penentuan jenis bidang longsor menunjukkan bahwa untuk lereng dengan kemiringan $30^{\circ}<\beta<\beta 60^{\circ}$ bidang longsor lingkaran yang terjadi hanya pada kaki lereng. (Salmasi F et.al., 2019) 


\section{Metode Penelitian}

Pada kegiatan ini, dilakukan beberapa tahapan pekerjaan seperti yang ditunjukkan pada Gambar 1. Tahapan survei lapangan dan pengumpulan data primer terdiri dari tahap reconnaissance, tahap pemetaan dan dan investigasi geologi, dan tahap survei dan investigasi geoteknik. Tahap reconnaissance bertujuan untuk mengetahui kondisi geografis dan geologi daerah penelitian. Tahap survei dan investigasi geologi bertujuan untuk mengetahui kondisi morfologi, kondisi geologi, identifikasi titik longsor serta pengambilan sampel tanah undisturbed dengan mempertimbangkan tingkat kerentanan gerakan tanah serta kondisi geologi teknik. Tahap survei dan investigasi geoteknik yang dilakukan berupa pengukuran geometri lereng, pemantauan jenis gerakan massa, kondisi pembebanan, tata guna lahan, dan kondisi muka air tanah. Hasil investigasi ini digunakan sebagai data pendukung dalam melakukan analisis stabilitas lereng dan juga sebagai acuan evaluasi data hasil analisis dengan kondisi nyata di lapangan. Data hasil investigasi geoteknik berupa data hasil pengujian laboratorium terhadap sampel tanah untuk mendapatkan parameter berupa: 1) Berat volume-ASTM D635; 2) Kadar air- ASTM D2216-71; 3) Gravitasi khusus - ASTM D854-10; 4) Batas-batas Atterberg -ASTM D 423-66 - D 424-59; 5) Uji distribusi ukuran butiran tanah - D422-72; 6) Uji geser langsung - ASTM D3080-03; 7) Uji triaksial UUASTM D2850. Selain itu, juga diperoleh data geometri lereng sebagai masukan dalam analisis stabilitas lereng pada daerah kajian.

Pada penelitian ini, terdapat 3 metode penanganan yang direncanakan yaitu: metode kontrol, metode perkuatan dan metode kombinasi kontrol-perkuatan. Konsep penanganan longsor diberikan dalam bentuk basic design dan dicontohkan pada salah satu titik longsor. Analisis kestabilan lereng pada penelitian ini menggunakan metode keseimbangan batas. Perhitungan stabilitas lereng metode kesetimbangan batas (limit plastic equilibrium) didasari oleh kriteria keseimbangan gaya-gaya dan atau momen yang bekerja pada massa tanah. Kriteria tersebut harus terpenuhi sebagai tolok ukur kestabilan lereng yang ditunjukkan dengan nilai faktor aman (Cornforth, 2005). Dikarenakan lereng tanah bukan material yang kaku dan percepatan puncak gempa terjadi dalam waktu yang singkat. Menurut Kramer (1996), dalam pelaksanaannya digunakan percepatan yang jauh lebih rendah dibandingkan percepatan puncaknya. Meskipun sebenarnya pemilihan koefisien seismik masihlah sangat subjektif, koefisien seismik yang digunakan adalah yang direkomendasikan oleh (Melo, C. dan Sharma, S., 2004) dengan $F S>1$ adalah 1/2 s.d. 1/3 dari PGA.

Dalam penelitian ini, investigasi kestabilan lereng dilakukan dengan metode kesetimbangan batas. Analisis stabilitas lereng dilakukan untuk memberikan gambaran mengenai tingkat kestabilan lereng, tingkat kestabilan ini dinyatakan dalam suatu koefisien yang disebut dengan faktor aman. Faktor aman $(S F)$ merupakan perbandingan antara gaya yang menahan dengan gaya yang menggerakkan seperti ditunjukkan pada Persamaan (1). Metode irisan untuk menentukan nilai faktor aman digunakan dalam penelitian dengan bantuan program Slope/W.

$$
S F=\frac{\tau}{\tau_{d}}=\frac{c+\sigma \tan \phi}{c_{d}+\sigma \tan \phi_{d}}
$$

dengan, $\tau$ adalah tahanan geser maksimum yang dapat dikerahkan oleh tanah $\left(\mathrm{kN} / \mathrm{m}^{2}\right)$ dan $\tau_{d}$ adalah tegangan geser yang terjadi akibat gaya berat tanah yang akan longsor $\left(\mathrm{kN} / \mathrm{m}^{2}\right)$.

Morgenstern dan Price (1965) mengembangkan metode analisis dengan memperhitungkan parameter variasi kuat geser dan tekanan air pori dalam tanah. Kesetimbangan setiap-gaya-gaya normal dan momen yang bekerja pada setiap irisan dari bidang longsor diilustrasikan pada Gambar 2. 


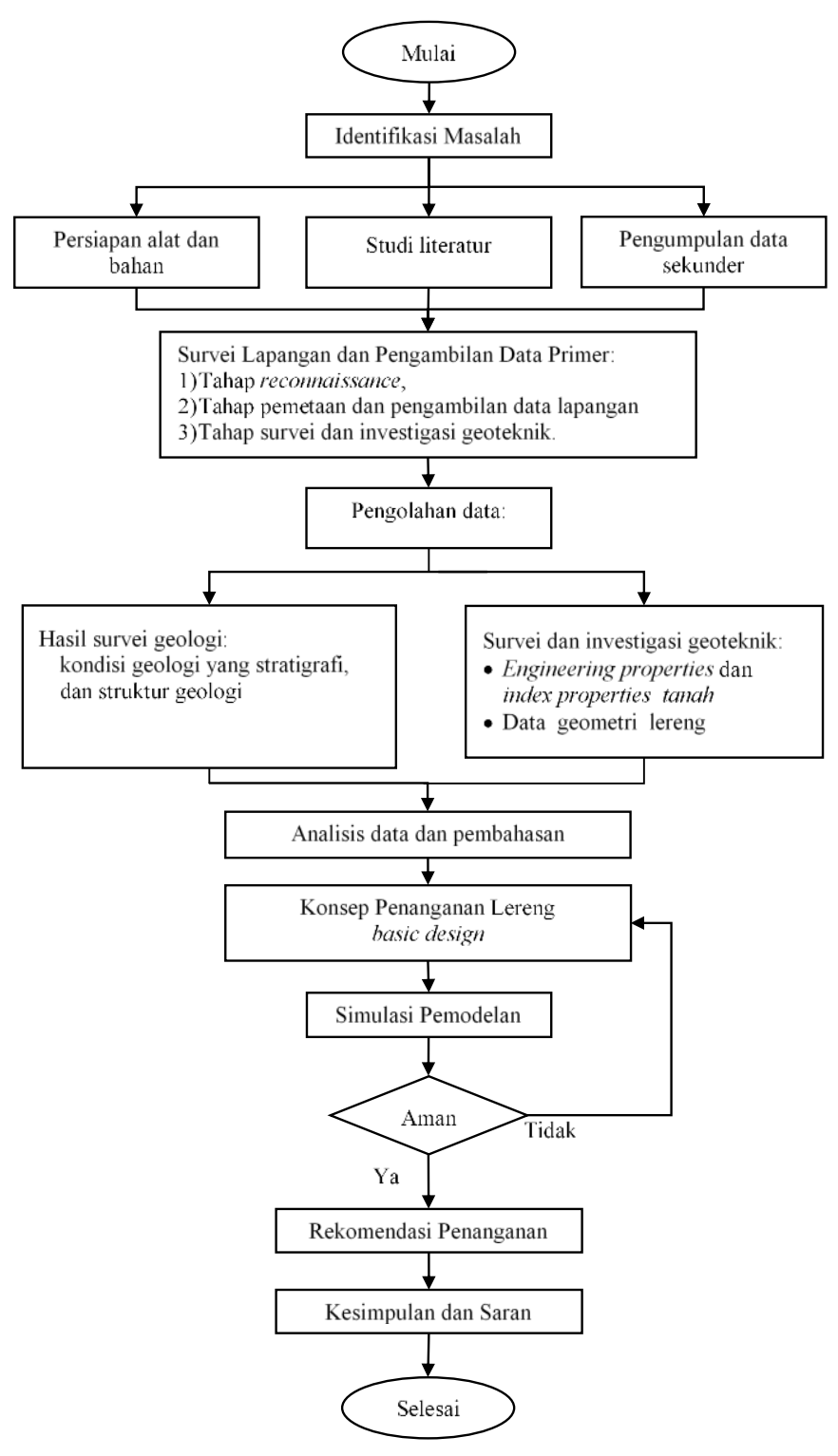

Gambar 1 Tahapan penelitian

Dalam metode ini, asumsi penyederhanaan dilakukan untuk menunjukkan hubungan antara gaya geser di sekitar irisan $(X)$ dan gaya normal di sekitar irisan $(E)$ melalui Persamaan (2):

$$
X=\lambda f(x) E
$$

dengan $f(x)$ adalah asumsi dari sebuah nilai fungsi dan $\lambda$ adalah suatu faktor pengali yang nilainya akan diasumsikan dalam perhitungan.

Nilai dari asumsi yang tidak diketahui dalam metode Morgenstern-Price yaitu factor of safety $(S F)$, faktor pengali $(\lambda)$, gaya normal yang bekerja pada dasar bidang irisan $(P)$, gaya di sekitar bidang irisan yang bekerja secara horizontal dan titik di mana gaya di sekitar bidang irisan (Thrust Line). Dari hasil analisa dengan kesetimbangan maka asumsi 
di atas akan diketahui, dan komponen gaya geser yang bekerja di sekitar bidang irisan $(X)$ dapat dihitung dengan Persamaan (3).

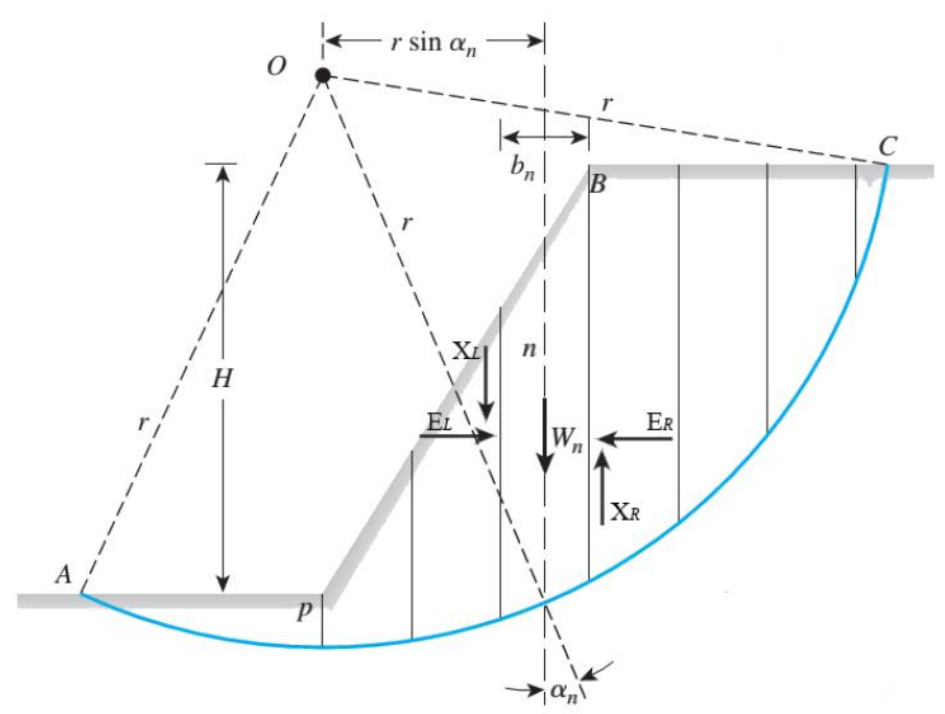

Gambar 2 Gaya-gaya yang bekerja pada metode Morgenstern-Price

$$
P=\frac{\left[W_{a}-\left(X_{R}-X_{L}\right]-\frac{1}{F}\left(c^{\prime} l \sin \alpha-u l\right)\right.}{\cos \alpha\left(l+\tan \alpha \frac{\tan \phi^{\prime}}{F}\right)}
$$

dengan,

$P \quad=$ Gaya normal $(\mathrm{kN})$

$c^{\prime} \quad=$ Kohesi (kondisi undrained diambil $c_{u}$, kondisi drained digunakan $\left.c^{\prime}\right)\left(\mathrm{kN} / \mathrm{m}^{2}\right)$

$W_{n} \quad=$ Gaya akibat beban tanah ke- $n(\mathrm{kN})$

$\alpha=$ Sudut antara titik tengah bidang irisan dengan titik pusat busur bidang longsor $\left({ }^{\circ}\right)$

$\phi^{\prime} \quad=$ Sudut geser tanah (analisa kondisi undrained nilai sudut geser 0$)\left({ }^{\circ}\right)$

$u \quad=$ Tekanan air pori $\left(\mathrm{kN} / \mathrm{m}^{2}\right)$

$X_{R}, X_{L}=$ Gaya gesek yang bekerja di tepi irisan $(\mathrm{kN})$

Dalam metode ini, analisa faktor aman keamanan dilakukan dengan dua prinsip yaitu kesetimbangan momen $\left(F_{m}\right)$ dan kesetimbangan gaya $\left(F_{f}\right)$. Faktor keamanan dari prinsip kesetimbangan momen dijabarkan menurut Persamaan (4) sebagai berikut:

$$
F_{m}=\frac{\sum\left[c^{\prime} l+(p-u l) \tan \phi^{\prime}\right]}{\sum W \sin \alpha}
$$

Dan nilai faktor keamanan dengan prinsip kesetimbangan gaya: 


$$
F_{f}=\frac{\sum\left[c^{\prime} l+(p-u l) \tan \phi^{\prime}\right] \cos \alpha}{\sum P \sin \alpha}
$$

Pada proses iterasi pertama, gaya geser di sekitar irisan $\left(X_{R}, X_{L}\right)$ diasumsikan nol. Kemudian pada proses iterasi selanjutnya gaya tersebut didapatkan dari rumus Persamaan (6):

$$
\left(E_{R}-E_{L}\right)=P \sin \alpha-\frac{1}{F}\left[c^{\prime} l+(p-u l) \tan \phi^{\prime}\right] \cos \alpha
$$

Gaya geser tersebut dihitung dengan mengasumsikan nilai $\lambda$ dan $f(x)$. Selanjutnya dalam penelitian ini perhitungan nilai faktor aman dilakukan dengan bantuan program Slope/W.

\section{Hasil dan Pembahasan}

\subsection{Hasil Survei Geologi dan Geoteknik}

Pekon Waykerap termasuk dalam Peta Geologi Lembar Kota Agung yang formasi batuan penyusunnya apabila diurutkan dari yang berumur relatif lebih muda ke yang berumur relatif lebih tua adalah Aluvium (Qa), Batuan Gunungapi Kuarter Muda (Qhv), Formasi Semung (QTse), Formasi Bal (Tmba), Formasi Seblat (Toms), Formasi Hulusimpang (Tomh), Batuan Terobosan (Tm) (Amin, T.C. dkk., 1993). Pada daerah penelitian ini, terdapat dua jenis batuan, yaitu andesit dan breksi. Breksi dijumpai sebagai material longsoran yang bercampur dengan batuan beku lainnya. Sedangkan batuan andesit merupakan batuan asli penyusun geologi daerah ini. Kedua batuan ini dapat diperkirakan terbentuk pada Oligosen Akhir hingga Miosen Awal berdasarkan analisis aktivitas vulkanisme batuan Formasi Hulusimpang (Tmoh). Berdasarkan struktur geologi (Gambar 3), daerah ini dilalui oleh sesar dan kelurusan sehingga memiliki potensi bencana geologi salah satunya adalah bencana longsor. Kondisi struktur geologi daerah penyelidikan ditandai dengan pola-pola kelurusan hasil dari bentukan morfologi yang dikontrol oleh aktivitas endogenik

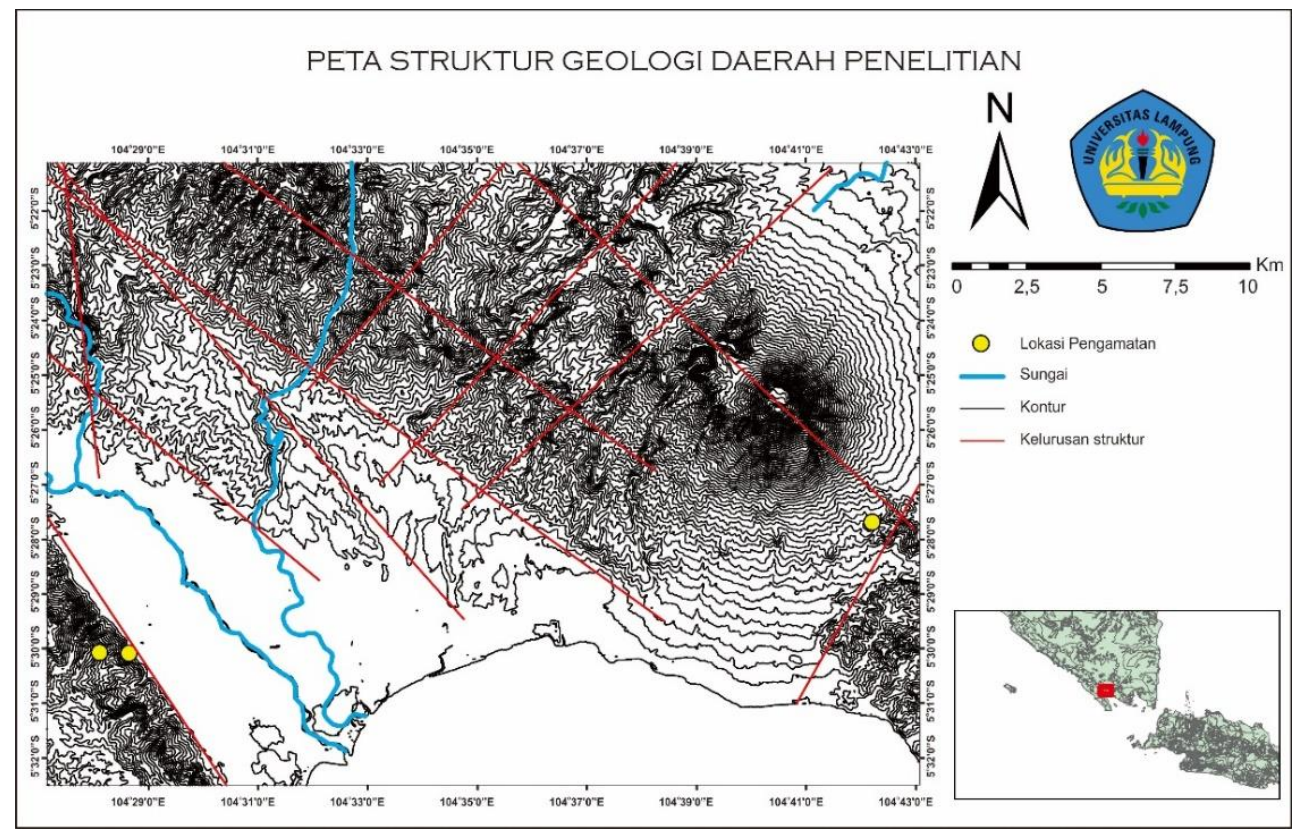

Gambar 3. Struktur geologi daerah penelitian

Pada daerah ini terdapat beberapa titik longsoran yang mengarah ke sungai dan dekat dengan jalan lintas barat dan pemukiman penduduk. Berdasarkan pengamatan di lapangan dan foto udara 
(Gambar 4), dua bidang longsor yang besar memiliki karakteristik dengan sudut lereng sekitar $50^{\circ}$ dan tinggi \pm 30 meter. Dua longsor lainnya berukuran lebih kecil dengan ketinggian \pm 7 dan \pm 8 meter dan sudut kemiringan lereng sekitar sekitar $50^{\circ}$. Kondisi sekitar lereng didominasi oleh semak belukar dan pepohonan. Sebagian besar material longsoran terbawa oleh aliran debris hingga ke pemukiman penduduk dan lahan pertanian warga. Sebagai penanganan sementara, pada sisi kiri aliran sungai dibuat tanggul dengan tinggi $\pm 2,5$ meter untuk membelokkan aliran debris supaya tidak mengarah ke pemukiman warga. Saat pengamatan di lapangan, dilakukan pengambilan sampel dengan tabung uji untuk mendapatkan parameter sifat fisik dan mekanik lapisan tanah.

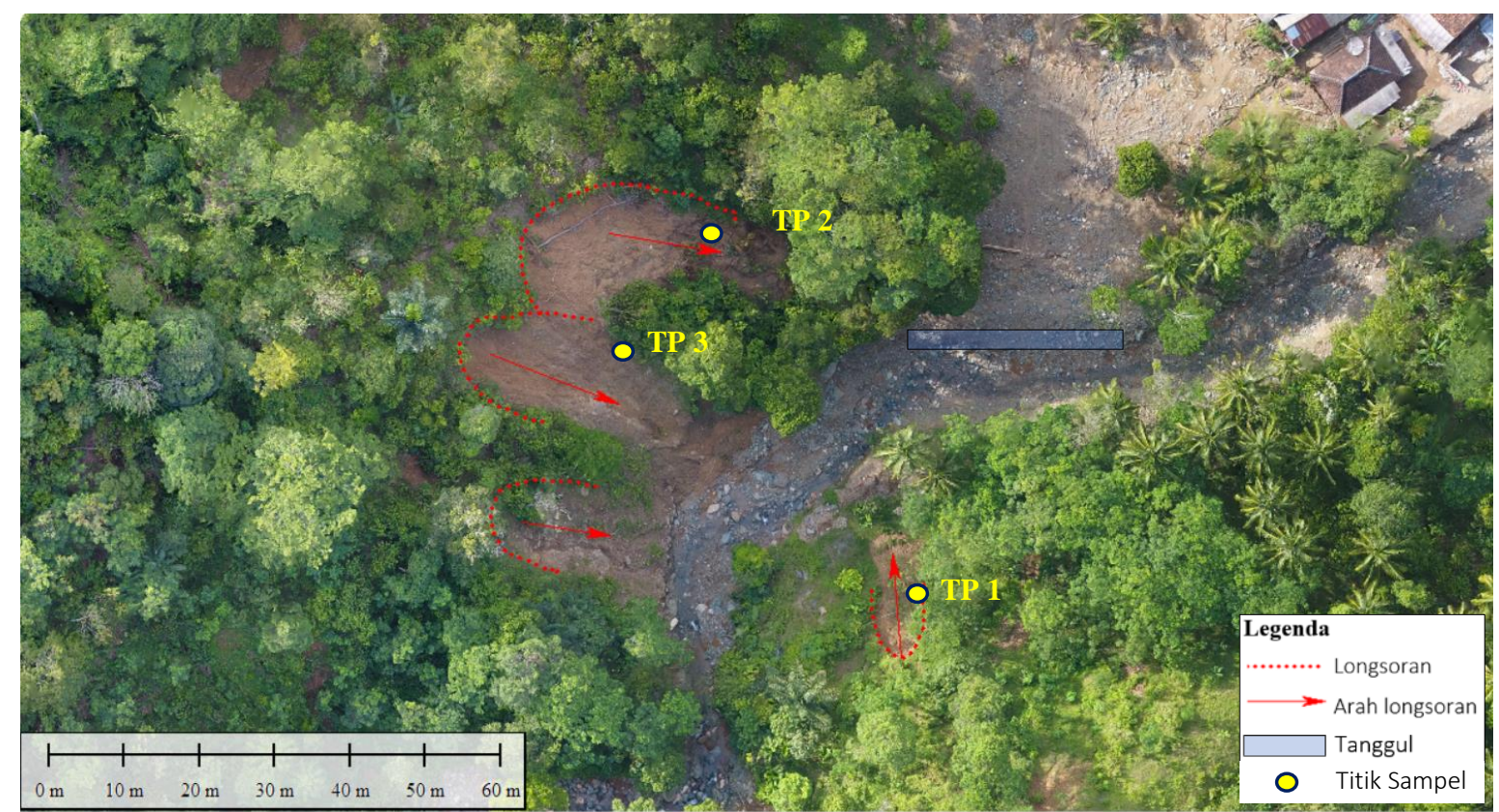

Gambar 4 Poto udara penampakan longsoran di lokasi penelitian

Hasil uji laboratorium terhadap 3 titik pengambilan sampel tanah di area sekitar longsor Pekon Waykerap menghasilkan parameter index properties dan engineering properties. Uji distribusi ukuran butiran memberikan informasi persentase butiran kasar (tertahan saringan No.200) dan butiran halus (lolos saringan No.200). Untuk butiran halus, batas-batas Atterberg memberikan informasi batas cair, batas plastis dan batas susut tanah. Secara umum tanah di daerah ini diklasifikasikan sebagai SM-SC yaitu pasir berlanau (campuran pasir lanau) atau pasir berlempung (campuran pasir lempung) dan CL yaitu lempung anorganik dengan plastisitas rendah sampai dengan sedang, lempung berkerikil, lempung berpasir, lempung berlanau, lempung "kurus" (lean clays) berdasarkan klasifikasi USCS (Das, 2006). Parameter kuat geser diperoleh dari hasil uji geser langsung dan triaksial UU. Rangkuman hasil pengujian ditambilkan pada Tabel 1.

\subsection{Data pengujian tanah dan pemantauan longsor}

\subsection{Penyebab dan mekanisme longsor}

Pergerakan pada lereng yang tersusun oleh massa tanah akan membentuk bidang gelincir berupa translasional, bidang datar, membaji, setengah lingkaran, ataupun kombinasi beberapa bentuk bidang gelincir (Abramson, 1996). Berdasarkan pengamatan di lapangan, tipe longsor yang terjadi 
Tabel 1 Hasil uji laboratorium sampel tanah

\begin{tabular}{|c|c|c|c|c|c|c|c|c|c|c|}
\hline \multirow[t]{2}{*}{$\begin{array}{r}\text { Test } \\
\text { Point }\end{array}$} & \multirow[t]{2}{*}{$\begin{array}{l}\text { Moisture } \\
\text { content }\end{array}$} & \multirow[t]{2}{*}{$\begin{array}{l}\text { Specific } \\
\text { Gravity }\end{array}$} & \multirow[t]{2}{*}{$\begin{array}{l}\text { Liquid } \\
\text { Limit }\end{array}$} & \multirow[t]{2}{*}{$\begin{array}{l}\text { Plastic } \\
\text { Limit }\end{array}$} & \multirow[t]{2}{*}{$\begin{array}{l}\text { Plasticity } \\
\text { Index }\end{array}$} & \multirow[t]{2}{*}{$\begin{array}{l}\text { Finer } \\
\# 200\end{array}$} & \multicolumn{4}{|c|}{ Strength Parameters } \\
\hline & & & & & & & Direct & hear & Triaxial, UL & \\
\hline No & $w_{N},(\%)$ & $\boldsymbol{G}_{s}$ & $\begin{array}{l}L L, \\
(\%)\end{array}$ & $\begin{array}{l}P L, \\
(\%)\end{array}$ & $P I,(\%)$ & $(\%)$ & $\phi\left(^{0}\right)$ & $\begin{array}{l}c \\
\left(\mathrm{~kg} / \mathrm{cm}^{2}\right)\end{array}$ & $\phi\left({ }^{0}\right)$ & $\begin{array}{l}c \\
\left(\mathrm{kN} / \mathrm{m}^{2}\right)\end{array}$ \\
\hline ТP-01 & 27,53 & 2,669 & 32,71 & 23,55 & 9,15 & 39,38 & 30,7 & 0,123 & - & - \\
\hline TP-02 & 31,99 & 2,492 & 35,69 & 27,19 & 8,50 & 63,12 & 25,3 & 0,094 & 11,0 & 26,1 \\
\hline TP-03 & 38,96 & 2,491 & 47,88 & 28,85 & 19,03 & 61,94 & 23,6 & 0,145 & - & - \\
\hline
\end{tabular}

dapat diklasifikasikan sebagai gabungan dari longsoran rotasi dan translasi. Bidang longsoran pada bagian yang telah mengalami longsor terlihat membentuk bidang rotasi pada bagian permukaan dan datar pada bagian lainnya. Litologi berupa batu andesit dan material longsoran berupa breksi vulkanik dengan tingkat pelapukan yang tinggi sehingga membentuk lapisan tanah yang tebal. Lapisan tanah yang terdiri dari lempung monmorilonit yang yang berada di atas batuan keras berupa andesit yang sangat rentan menimbulkan gerakan tanah bila dipicu oleh air.

Ketika terjadi infiltrasi air hujan ataupun rembesan air tanah, massa lereng akan bertambah dan menyebabkan gaya penggerak massa tanah menjadi semakin besar, sedangkan tahanan geser tanah menurun akibat penambahan tegangan air pori dalam tanah. Di sisi lain, gerusan oleh aliran air sungai yang terus menerus terjadi pada kaki lereng mengakibatkan gaya penahan lereng berkurang. Geometri lereng dengan ketinggian di atas $12 \mathrm{~m}$ dengan kemiringan yang curam menambah gaya penggerak pada tubuh lereng. Kondisi tersebut menyebabkan stabilitas lereng menurun dan lereng mengalami longsor. Longsor yang terjadi membawa material bahan rombakan berupa pepohonan dan vegetasi lainnya.

\subsection{Analisis Kestabilan Lereng}

Longsor di Pekon Waikerap Lereng eksisting dimodelkan dan dianalisis menggunakan Slope/W dengan metode keseimbangan batas Morgenstern Price. Konsep penanganan yang direkomendasikan untuk lereng di Pekon Waykerap melakukan penataan geometri lereng serta memberi struktur perkuatan pada kaki lereng berupa bronjong yang ditunjukkan pada Gambar 5. Konsep desain awal adalah mengurangi gaya penggerak (metode kontrol). Pemotongan lereng akan menghilangkan sebagian beban baik oleh tanah maupun air. Penataan geometri lereng dapat dilakukan dengan melandaikan kemiringan lereng menjadi $1 \mathrm{H}: 1 \mathrm{~V}$, serta pembuatan trap-trap (benching) dengan yang dilengkapi dengan berm sebesar 2,5 meter. Penataan lereng dengan traptrap (benching) ini dilakukan untuk mengurangi gaya penggerak dalam tubuh lereng karena berdasarkan data topografi, kemiringan lereng sangat curam $\left(>50^{\circ}\right)$. Sedangkan bronjong adalah bagian dari menambah perkuatan lereng, menggunakan SNI 03-0090-1999 dengan ketinggian menyesuaikan kondisi lereng. Kombinasi metode ini yang kemudian dianalisis faktor amannya sampai diperoleh nilai FS yang aman.

Permukaan lereng juga harus ditutupi dengan gebalan rumput dan diberikan drainase permukaan. Hal ini bertujuan untuk melindungi permukaan lereng dari erosi serta mengurangi infiltrasi air ke dalam lereng. Bronjong harus dilengkapi dengan filter (geosintetik) untuk menjaga aliran air mengalir tanpa adanya erosi pada bagian kaki lereng. Penanganan dengan membangun saluran drainase permukaan dan pemasangan gebalan rumput direkomendasikan untuk mencegah infiltrasi air ke dalam lereng serta erosi permukaan akibat limpasan air hujan. Keberadaan sungai di bagian kaki lereng perlu menjadi catatan penting terkait tingkat kerawanan terjadinya banjir bandang apabila terjadi longsor yang lebih besar dan menutup aliran sungai. 


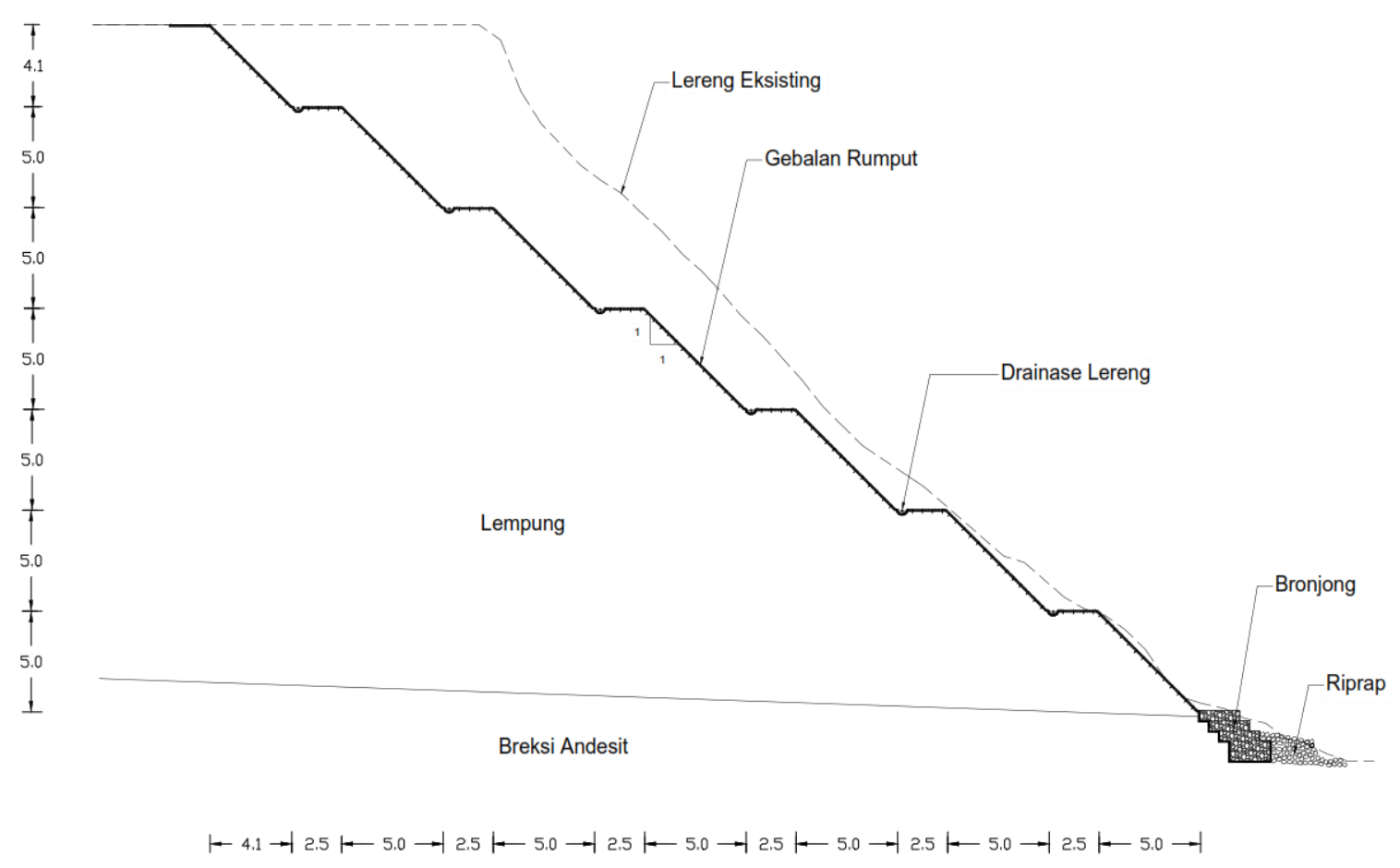

Gambar 5 Konsep penanganan longsor di Pekon Way Kerap, Semaka

Pemodelan lereng dan analisisis stabilitas dilakukan setelah penanganan. Pemodelan dilakukan dengan metode keseimbangan batas (limit equilibrium) yaitu Slope/W untuk memperkirakan bidang longsor pada saat longsor terjadi, kondisi setelah longsoran (kondisi saat ini) dan kondisi setelah penanganan. Geometri longsoran, data parameter fisik dan kuat geser tanah yang telah diperoleh sebelumnya digunakan dalam pemodelan dengan menyesuaikan kondisi real di lapangan. Metode Morgenstern-Price digunakan dalam analisis karena merupakan bidang longsor berbentuk non-circular dan merupakan metode yang paling lengkap dengan memperhitungkan kesetimbangan gaya horizontal, vertikal dan kesetimbangan momen.

Hasil simulasi pada longsor di Pekon Waykerap dengan metode Morgenstern and Price, menunjukkan bahwa kedalaman bidang gelincir longsoran eksisting adalah 5,1 m dengan faktor aman 1,049 (statis) dan 0,838 (dinamis) (Tabel 2A). Nilai faktor aman $S F<1,07$ memiliki intensitas kejadian longsor yang sering terjadi (Bowles, 1989). Kondisi lereng setelah terjadinya longsor ini mirip dengan kondisi saat ini dengan bidang longsor yang hampir sama berdasarkan data topografi dari poto udara. Oleh karena itu parameter kuat geser tanah dalam pemodelan ini dapat digunakan.

Hasil simulasi pada lereng eksisting (Tabel 2B) menunjukkan bahwa lereng masih rentan mengalami longsor karena memiliki nilai faktor aman 1,092 (statis) dan 0,846 (dinamis). Longsor dapat terjadi apabila dipicu oleh kenaikan muka air tanah, gempa atau perubahan geometri lereng akibat pemotongan atau gerusan air pada kaki lereng.

Setelah penanganan dengan metode kontrol dan perkuatan seperti yang ditunjukkan pada pembahasan sebelumnya dilakukan analisis terhadap faktor aman lereng. Hasil simulasi (Tabel 2C) menunjukkan bahwa nilai faktor aman naik menjadi 1,298 (statis) dan 1,031 (dinamis). Berdasarkan pemodelan, lereng dinyatakan memiliki risiko kecil terhadap gerakkan massa tanah karena menghasilkan nilai faktor aman (safety factor) lebih dari 1,25 untuk kondisi statis dan lebih dari 1,00 untuk kondisi dinamis (Bowles, 1989). Hal itu menunjukkan bahwa dengan perkuatan bronjong, penataan geometri lereng, pemasangan drainase permukaan dan penggunaan gebalan rumput untuk mencegah erosi permukaan lereng dapat diterapkan pada lereng di daerah ini. 
Tabel 2 Hasil pemodelan longsor akiba beban statis dan dinamis di Pekon Waykerap

No

Beban statis

a)

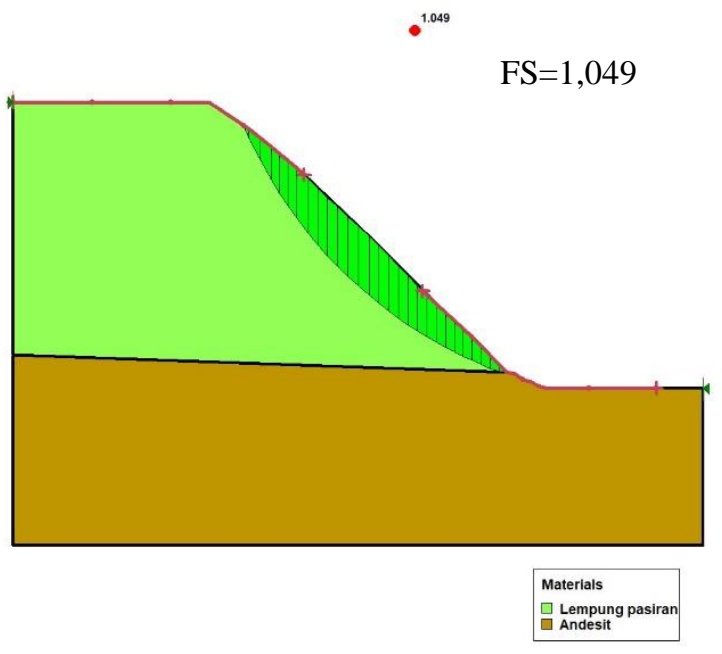

b)

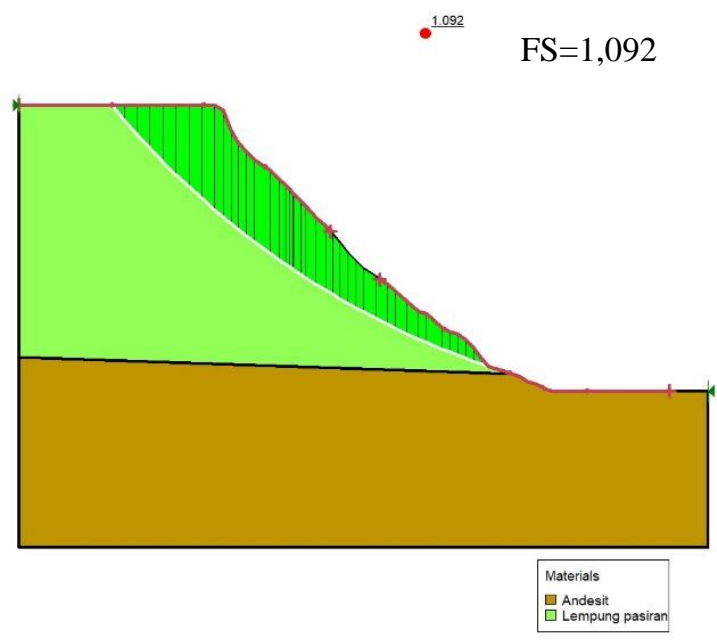

c)

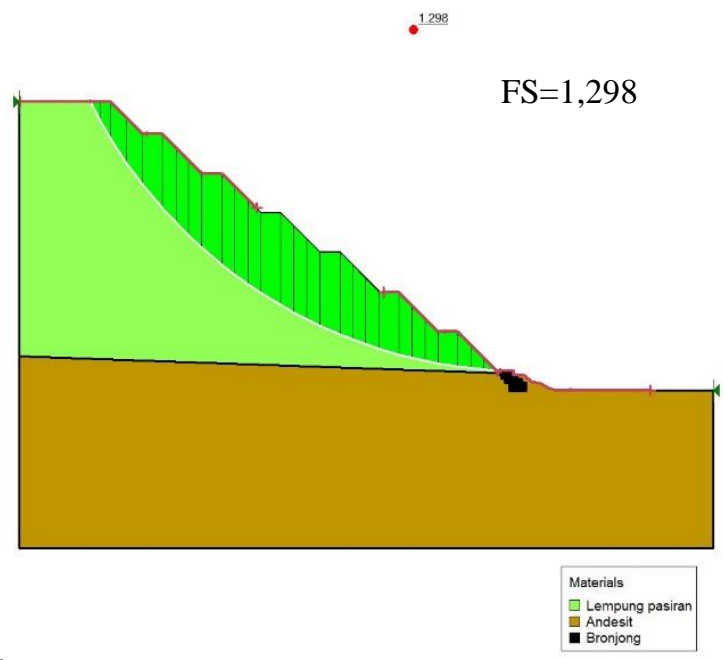

\section{Beban dinamis}

$\bullet^{0.838}$
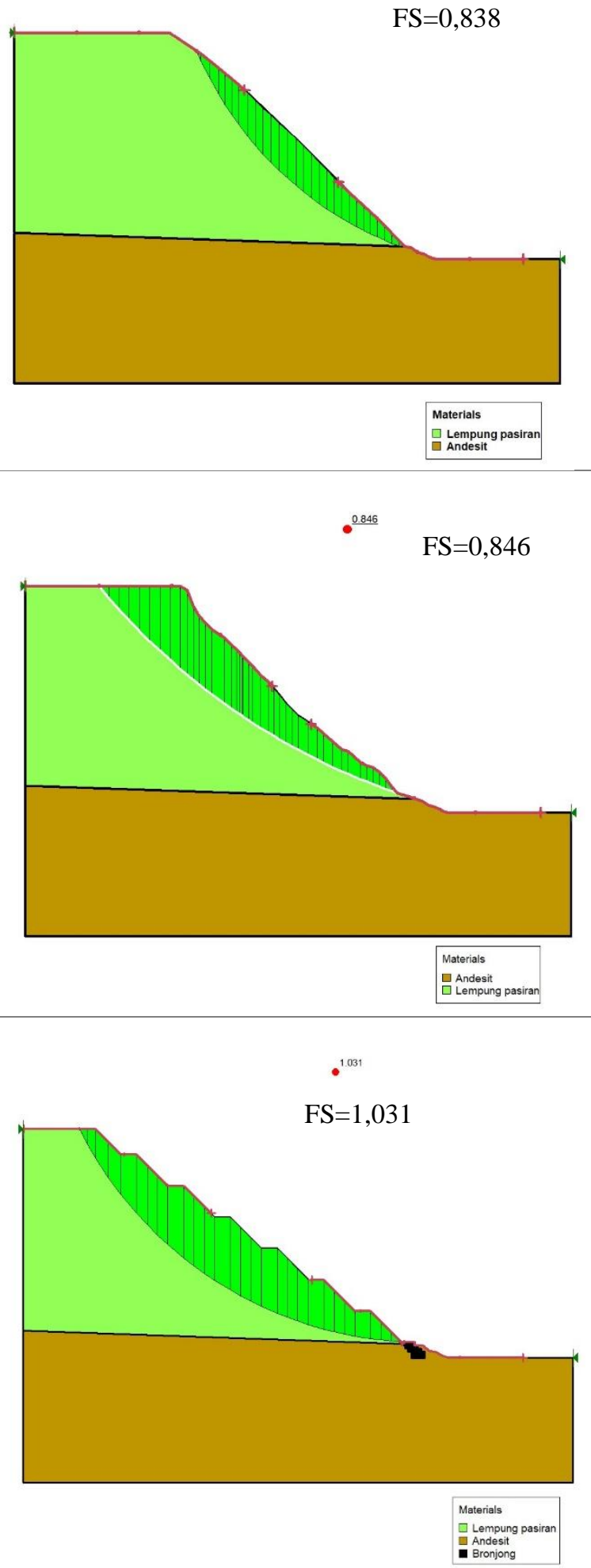


\section{Kesimpulan}

Hasil survei geologi menunjukkan bahwa pada pengamatan longsor di Pekon Waykerap memiliki litologi penyusun berupa andesit dan material longsoran berupa breksi vulkanik dengan tingkat pelapukan yang tinggi sehingga membentuk lapisan tanah yang tebal. Lapisan tanah yang terdiri dari lempung monmorilonit yang yang berada di atas batuan keras berupa andesit sangat rentan menimbulkan gerakan tanah bila dipicu oleh air. Hasil analisis stabilitas lereng pada contoh penanganan longsor di Pekon Waykerap menunjukkan bahwa dengan penanganan kombinasi metode kontrol dan perkuatan meningkatkan nilai faktor aman dari 1,092 (statis) dan 0,846 (dinamis) menjadi 1,298 (statis) dan 1,031 (dinamis) yang berarti lereng memiliki risiko kecil terhadap gerakkan massa tanah. Metode kontrol yang diterapkan berupa penataan lereng dengan membatasi ketinggian lereng sebesar 5 meter, mengatur kemiringan lereng menjadi $1 \mathrm{H}: 1 \mathrm{~V}$, memberikan bench/trap sebesar 2,5 meter serta penggunaan gebalan rumput dan drainase permukaan Metode perkuatan yang disarankan adalah pemasangan bronjong yang dilengkapi dengan filter pada kaki lereng. Dengan demikian, perencanaan basic design untuk penerapan tipikal penanganan longsor di Pekon Waykerap telah memenuhi kriteria lereng risiko rendah terhadap gerakan massa tanah.

Sebagai tindak lanjut dari penelitian ini, perlu dilakukan kajian yang komprehensif terhadap kejadian aliran debris yang terjadi di Wahkerap. Selain itu, survei dan kajian longsor yang lebih luas perlu dilakukan untuk memperoleh gambaran yang lebih detail terhadap upaya pengurangan risiko bencana longsor di Kabupaten Tanggamus. Upaya mitigasi non-struktural dapat dikaji dan diterapkan untuk penelitian selanjutnya karena memiliki biaya yang relatif lebih murah.

\section{Daftar Pustaka}

2013. Naskah Akademis Masterplan Pengurangan Risiko Bencana Tanah Longsor. Jakarta: BNPB.

Abramson L.W., Lee T.S., Sharma S., dan Boyce G.M., 1996. Slope Stability and Methods. John Wiley \& Sons, Inc. New York.

Amin, T.C., Sidarto, Santosa, S dan Gunawan, W., 1993. Peta Geologi Lembar Kota Agung, Sumatra, Pusat Penelitian dan Pengembangan Geologi.

Barber, A.J., Crow dan Milsom, J.S. 2005. Sumatra : Geology, Resources and Tectonic Evolution, London: The Geological Society London, pp.234-239.

Badan Nasional Penanggulangan Bencana, 2014. Indeks Risiko Bencana Indonesia (IRBI 2014), Jakarta.

Bishop AW (1955) The use of slip circle in the stability analysis of earth slopes. Geotechnique Vol. 5(1), pp 7-17

Bishop AW, Morgensrern NR (1960) Stability coefcients for earth slopes. Geotechnique Vol. 10(4), pp 129-147

Bowles, J.E. 1989. Physical and Geotechnical Properties of Soils, 2nd Edition, McGraw-Hill Book Company, New York.

Cornforth, D. H. 2005. Landslides in Practice Investigation, Analysis, and Remedial/Preventative Options in Soils. New Jersey: John Wiley and Sons, Inc., hal. $10-15$. 
Das, B. M., 2006. Principles of Geotechnical Engineering. Toronto: Nelson.

Fellenius W (1927) Erdstatische Berechnungen, revised edn. W. Ernst u. Sons, Berlin

Haji Azizi M, Kielanei F, Kielanei P (2015) Comparison of the methods of limit equilibrium in slope stability of embankments. In: First national conference on soil mechanics and engineering, Faculty of Civil Engineering, Shahid Rajaee University.

Janbu N (1973) Slope stability computations. In: Hirschfeld E, Poulos S (eds) Embankment dam engineering, Casagrande memorial volume. Wiley, New York, pp 47-86

Kramer SL. 1996. "Geotechnical Earthquake Engineering.” Prentice-Hall, Inc., Upper Saddle River, New Jersey 07458, pp. 434-437.

Lowe J, Karafath L (1960) Stability of earth dams upon drawdown. In: Proceedings of the frst pan American conference on soil mechanics and foundation engineering. Mexican Society of Soil Mechanics, Mexico, pp 537-552

Marcuson WF, Franklin AG. 1983. "Seismic Design, Analysis, and Remedial Measures to Improve the Stability of Existing Earth Dams - Corps of Engineers Approach", in Seismic Design of Embankments and Caverns, T.R. Howard, Ed., New York, ASCE.

Morgenstern, N.R., and Price, V.E. 1965. The Analysis of the Stability of General Slip Surfaces. Geotechnique, Vol. 15, pp. 79-93.

Melo, C. dan Sharma, S., 2004. Seismic Coeficient for Pseudostatic Slope Analysis. Vancouver.

Morgenstern NR (1963) Stability charts for earth slopes during rapid drawdown. Geotechnique Vol. 13(2), pp 121-133

Morgenstern NR, Price VE (1965) The analysis of the stability of general slip surfaces. Geotechnique Vol. 15(1), pp 79-93

Rahimi H (2013) Embankment dams, 4th edn. University of Tehran, Tehran.

Salmasi F., Pradhan B., and Nourani B., 2019. Prediction of the sliding type and critical factor of safety in homogeneous fnite slopes. Applied Water Science, Vol. 9, pp 158

Spencer E (1967) A method of analysis of the stability of embankments assuming parallel interslice forces. Geotechnique Vol. 17(1), pp 11-26

Steward T, Sivakugan N, Shukla SK, Das BM (2011) Taylor's slope stability charts revisited. Int J Geo-mech ASCE Vol. 11 (4), pp 348-352

U.S. Army Corps of Engineers (1970) Stability of earth and rock-fll dams. EM 1110-2-1902. U.S. Army Engineer Waterways Experiment Station, Vicksburg, MS 